\title{
Primary Prevention of Neglect in Children through Health Education for Adolescent Girls in West Sumatra, Indonesia
}

\author{
Meri Neherta $^{1 *}$ (D), Yonrizal Nurdin ${ }^{2}$ \\ ${ }^{1}$ Department of Pediatric and Maternity Nursing, Faculty of Nursing, Universitas Andalas, Padang, Indonesia; ${ }^{2}$ Department of \\ Psychiatric and Community Nursing, Faculty of Nursing, Universitas Andalas, Padang, Indonesia
}

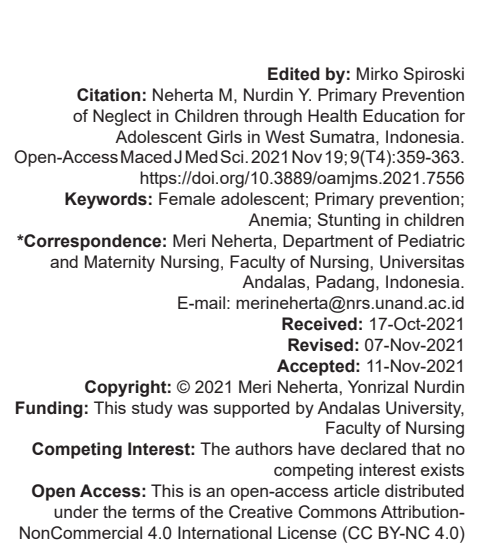

Introduction

A neglection is a form of violence that often occurs worldwide today [1]. In Indonesia, stunting is a real example of it. Stunting can increase the risk of infectious diseases, non-communicable diseases (NCDs), and emotional and behavioral disorders, which will inhibit their growth in the future.

At present, stunting is a global nutritional problem that occurs in many toddlers. In 2017, 150.8 million toddlers in the world were in stunting conditions [2]. Indonesia is ranked $3^{\text {rd }}$ in Southeast Asia, with $36.4 \%$ of stunting children, while West Sumatra is ranked $7^{\text {th }}$ in Indonesia, with a stunting rate of 37.2 in 2017 [3]. One of the causes of stunting in toddlers is born from a mother who has anemia during her teenage years [4].

Adolescents are an important group that is often forgotten in health programs, although public health in the future is very dependent on the health of adolescents at this time [5]. If a teenager has experienced malnutrition, they will surely give birth to LBW children [6], who will become stunted children [7]. Therefore, health intervention is crucial and needs to be done for female adolescents as they are prospective mothers who are expected to give birth to healthy children in the future [8].

\section{Materials and Methods}

This research is pseudo experimental research with the design of a one-group pretest-post-test design. The intervention was carried out 3 times to the number of samples of 397 female adolescents, given health education on the prevention of anemia, with teaching materials: 1) Healthy and balanced food for adolescents, 2) impact of anemia in adolescents, and 3) stunting in children. The media used for the learning activities consist of PPT presentations, videos, interactive discussions, sending messages on anemia prevention through WhatsApp media, and healthy food demonstrations for anemia prevention in female adolescents. Implementation of this intervention is school-based. This research was conducted from March to November 2019 in Talamau District, West Pasaman Regency. This research has passed the research ethics test from the Ethics Committee Team of the Faculty of Medicine, Andalas University No: 200/KEP/FK/2019. 


\section{Results}

This study involved 397 respondents (age range from 12 years to 19 years), with the most respondents aged 16 years (26.2\%). The intervention was given to female adolescents 3 times. The following is the average knowledge value and attitude value of respondents before and after the intervention.

From Table 1, it is known that the average value of respondents' knowledge and attitudes after the intervention has increased. The increase occurred in each intervention. However, the average increases in the value of knowledge and attitudes, the highest value occurred after the second intervention. The following are the results of the GLM repeated measure test.

Table 1: Average knowledge value and attitude score of respondents before and after the intervention

\begin{tabular}{llllllll}
\hline & N & Mean & Min & Max & Std & \multicolumn{2}{c}{ 95\% Confidence Interval } \\
\cline { 5 - 7 } & & & & & & Lower Bound & Upper Bound \\
\hline P1 (pre) & 397 & 12.90 & 7 & 17 & 2.246 & & \\
P2 (Int 1) & 397 & 14.42 & 9 & 27 & 2.227 & 15.242 & 15.630 \\
P3 (Int 2) & 397 & 16.79 & 11 & 20 & 1.805 & & \\
P4 (Int 3) & 397 & 16.88 & 11 & 20 & 1.725 & & 11.809 \\
S1 (pre) & 397 & 9.09 & 5 & 15 & 1.524 & 11.612 & \\
S2 (Int 1) & 397 & 12.24 & 7 & 15 & 1.339 & & \\
S3 (Int 2) & 397 & 13.80 & 10 & 16 & 1.922 & & \\
S4 (Int 3) & 397 & 13.88 & 9 & 16 & 1.863 & & \\
\hline
\end{tabular}

Table 2, the tests of within-subjects contrasts results show an increase in the average knowledge value and attitude value of the respondents with $p=0.00$.

Table 2: Average knowledge values and attitude scores of tests of within-subjects contrasts

\begin{tabular}{lll}
\hline Variable & Mean & p-value \\
\hline Knowledge & & \\
P2 versus P1 & 928.300 & 0.000 \\
P3 versus P2 & 1894.673 & 0.000 \\
P4 versus P3 & 948.176 & 0.000 \\
Attitude & & \\
S2 versus S1 & 1553.765 & 0.000 \\
S3 versus S2 & 1383.304 & 0.000 \\
S4 versus S3 & 687.222 & 0.000 \\
\hline
\end{tabular}

From Table 3, it can be seen that there was an increase in the average knowledge value and the average attitude value of the respondents after receiving the intervention, with $p=0.00$. The multivariate test value of $p=0.00$ also indicates the increase in both knowledge and attitude value. An increase in the average value of knowledge and attitudes of respondents can also be seen in the following graph:

Table 3: Average knowledge value and attitude value of tests of between-subject effects

\begin{tabular}{llll}
\hline Source & Measure & Mean & p-value \\
\hline Intercept & Attitude & 39354.010 & 0.000 \\
& Knowledge & 68377.490 & 0.000 \\
Respondent's description & Attitude & 304.227 & 0.000 \\
& Knowledge & 37.566 & 0.000 \\
\hline
\end{tabular}

From Figure 1, it is clear that the average knowledge value of the respondents increased after three interventions were carried out. The highest increase occurred after the second intervention.

From Figure 2, it can be seen that there is a change in the average attitude value of the respondents

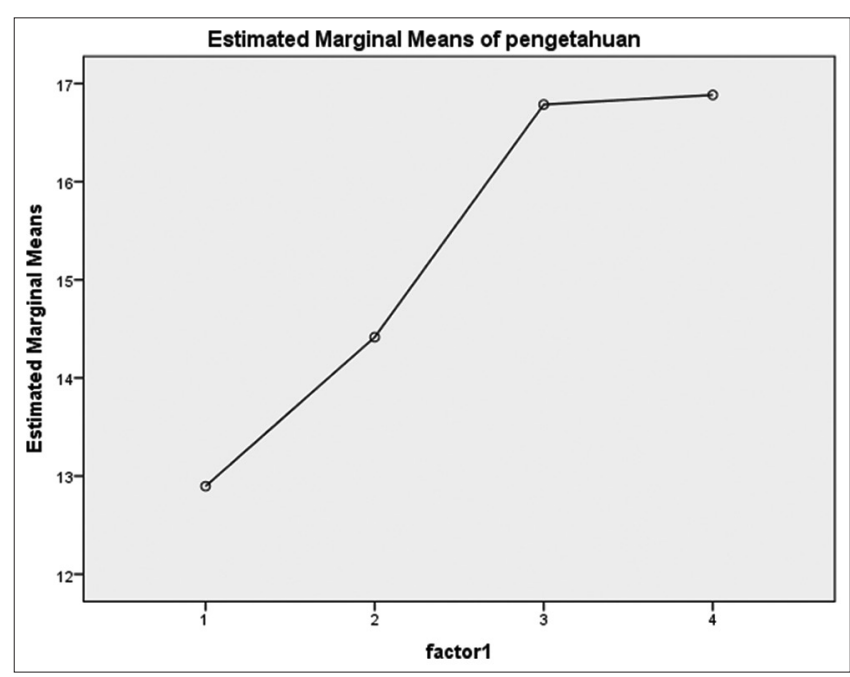

Figure 1: Chart changes in the knowledge of respondents in general at 4 times measurement

after the intervention was carried out 3 times. However, the most significant increase was after the second intervention.

The average value of knowledge and attitudes at all levels of age has increased after receiving the intervention. This increase is shown in Figure 3.

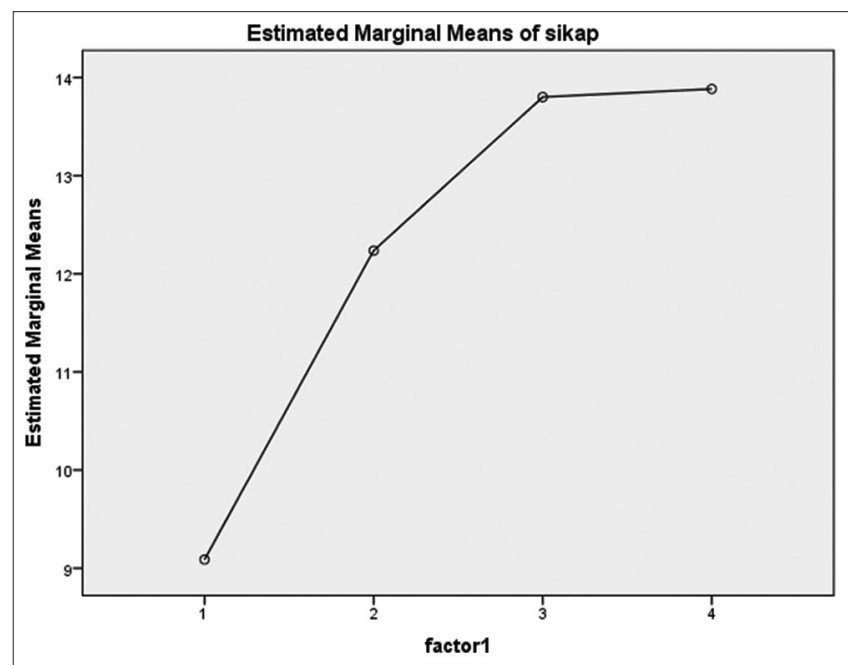

Figure 2: Chart changes in the attitude of respondents in general at 4 times measurement

From Figure 3, it is clear that there is an increase in the average value of knowledge in respondents from each age group after the third intervention. This situation is also the same as the average value of the respondent's attitude, as shown in Figure 4.

From Figure 4, it is clear that there is an increase in the average value of the attitude measurement of all age groups after getting the intervention 3 times. The increase in the average value of knowledge and attitudes needs to be categorized to see if the change in the average value of knowledge and attitudes is as expected. Tables 4 and 5 show a categorized distribution frequency changes in the average values of knowledge and attitude. 


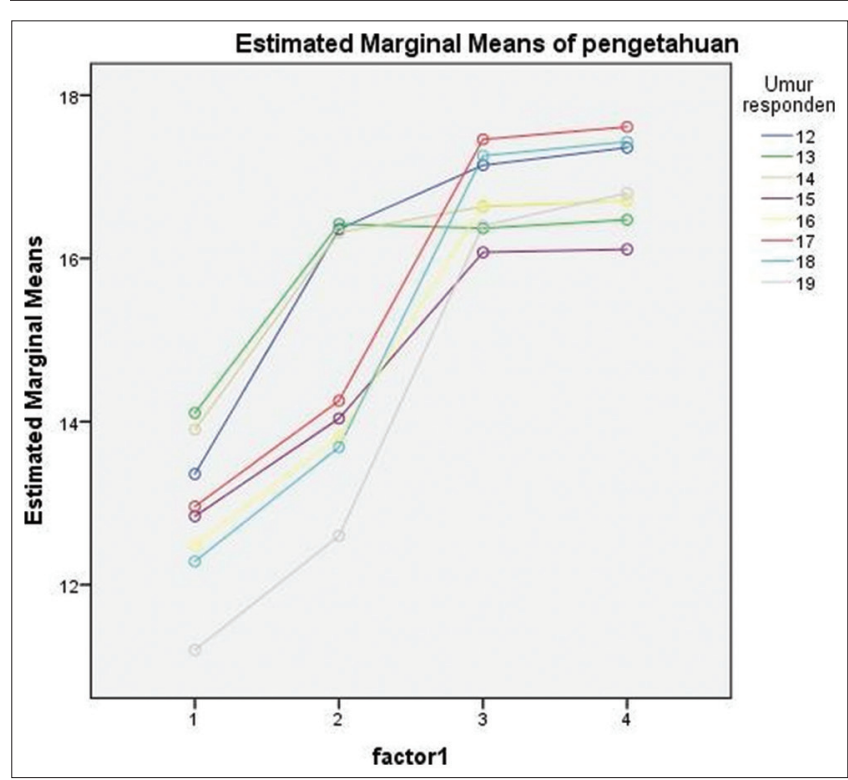

Figure 3: Graph of changes in respondents' knowledge in terms of age characteristics in four measurements

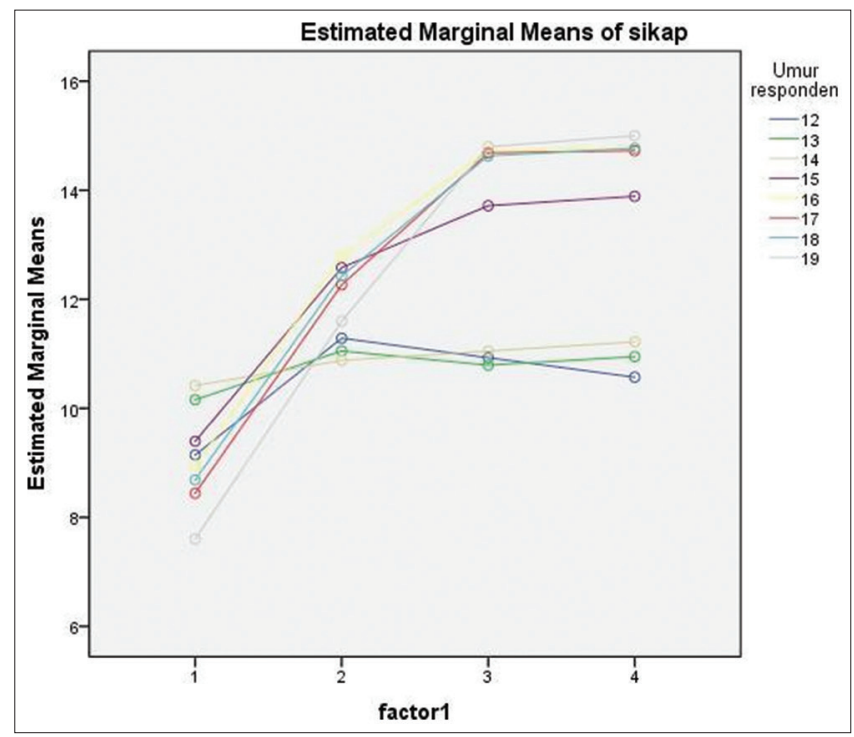

Figure 4: Graph of changes in respondents' attitudes seen from age characteristics in four measurements

Table 4: Distribution of knowledge frequency after getting intervention 3 times

\begin{tabular}{|c|c|c|c|c|c|c|c|c|}
\hline & \multicolumn{2}{|l|}{$\mathrm{P} 1$} & \multicolumn{2}{|l|}{ P2 } & \multicolumn{2}{|l|}{ P3 } & \multicolumn{2}{|l|}{ P4 } \\
\hline & $\mathrm{F}$ & $\%$ & $f$ & $\%$ & $f$ & $\%$ & $f$ & $\%$ \\
\hline \multicolumn{9}{|l|}{ Knowledge } \\
\hline High & 44 & 11.1 & 132 & 33.2 & 297 & 74.8 & 304 & 76.7 \\
\hline Moderate & 222 & 55.9 & 228 & 57.4 & 99 & 24.9 & 92 & 23 \\
\hline Low & 131 & 33.0 & 37 & 9.3 & 1 & 0.3 & 1 & 0.3 \\
\hline Total & 394 & 100 & 394 & 100 & 394 & 100 & 394 & 100 \\
\hline
\end{tabular}

Table 5: Attitude frequency distribution after getting the intervention 3 times

\begin{tabular}{|c|c|c|c|c|c|c|c|c|}
\hline & \multicolumn{2}{|l|}{ S1 } & \multicolumn{2}{|l|}{ S2 } & \multicolumn{2}{|l|}{ S3 } & \multicolumn{2}{|l|}{ S4 } \\
\hline & $\mathrm{F}$ & $\%$ & $f$ & $\%$ & $\mathrm{~F}$ & $\%$ & $f$ & $\%$ \\
\hline \multicolumn{9}{|l|}{ Attitude } \\
\hline Supportive & 152 & 38.3 & 176 & 44.3 & 259 & 65.2 & 290 & 73.0 \\
\hline Unsupportive & 245 & 61.7 & 221 & 55.7 & 138 & 34.8 & 107 & 27.0 \\
\hline Total & 397 & 100 & 397 & 100 & 397 & 100 & 397 & 100 \\
\hline
\end{tabular}

Table 4, before the intervention, the high knowledge category was only $11.1 \%$, moderate $55.9 \%$, and low $33 \%$. After the third intervention, the high knowledge category rose drastically to $76.6 \%$, and low knowledge was only $0.3 \%$ (one person). For changes in attitude categories are shown in Table 5.

Table 5 shows that there is a change in the attitude category of the respondents. Before getting the intervention, respondents in the category of supportive attitude were only $38.3 \%$, after 3 times the intervention increased to $73 \%$. The unsupportive attitude before the intervention was $61.7 \%$, which changed to $27 \%$ after getting the interventions.

\section{Discussion}

Based on this study, we suggest that interventions can increase the average value of knowledge and the average value of the attitude of the respondents. The well-prepared learning materials and interventions' frequencies (3 times) have resulted in a positive outcome [9]. The principle of learning that is needed is the theory of power psychology. According to this theory, learning is training the powers that exist in humans, consisting of the power to observe, perceive, remember, imagine, feel, and think [10]. These powers will develop by continuous and repetitive practice, just as a knife that is repeatedly sharpened will become sharp [11].

The repetition method, physiologically, will increase the dendrites and thicken the axon membrane, strengthening the network between nerve cells. Dendrites and axons are fibers that connect nerve cells, which strengthen memory power in the brain [12]. Likewise, with the AIR (Auditory Intellectually Repetition) method, learning by listening, learning by thinking, and repetition means deepening, expanding, and strengthening [13]. In this research, the interventions were carried out under the principle of learning with the repetition method. Through repetition, respondents will have a good and deep understanding [14].

Development during adolescence greatly determines the quality of a person to become an adult individual [15]. Nutritional problems that occur in adolescence will increase susceptibility to disease at the age of adolescent girls who suffer from anemia are at risk of becoming women of childbearing age who are anemic and subsequently become anemic pregnant women, and even experience protein-energy deficiency [16]. This increases the chances of giving birth to a low birth weight (LBW) baby and stunting, complications during delivery, and several other pregnancy-related risks, and the risk of giving birth to a generation with nutritional problems [17]. 
In this study, the learning media used is adjusted to the learning style of the respondents [18]. Therefore, the research uses a variety of learning media, that is, presentations with power points and videos. The second intervention uses interactive discussions with illustrated stories, and the third intervention uses demonstrations. These methods increase the average knowledge and attitudes of respondents [19].

This study reveals essential evidence in plans to disseminate knowledge about anemia and its prevention in female adolescents [20]. In addition, this study also proves that building a comprehensive educational intervention can increase knowledge and attitudes among respondents and is very important to reduce cases of anemia in female adolescents as prospective mothers, to prevent stunting in toddlers [21].

\section{Conclusions and Suggestions}

The intervention model for preventing child neglects (stunting) through health education about anemia and its prevention can increase knowledge among female adolescents for stunting prevention in West Pasaman.

\section{Study limitations}

The study was only conducted with medical record data with a limited number of samples.

\section{Acknowledgment}

We would like to thank the Chancellor of Andalas University, Head of LPPM Andalas University and the Dean of the Faculty of Virginity who have provided assistance, both morally and materially, for the implementation of this research.

\section{References}

1. World Health Organization. 2018. Stunting is Measured by a Height-for-age Z-score of More Than 2 Standard Deviations Below the World Health Organization. Geneva: World Health Organization; 2018.

2. Republik Indonesia. Riset Kesehatan Dasar Kemenrian Kesehatan Republic Indonesia Tahun. Indonesia: Republik
Indonesia; 2018.

3. Rachmi CN, Agho KE, Li M, Baur LA. Stunting, underweight and overweight in children aged 2.0-4.9 years in Indonesia: Prevalence trends and associated risk factors. PLoS One. 2016b;11(5):e0154756 https://doi.org/10.1371/journal. pone. 0154756

PMid:27167973

4. Torlesse H, Cronin AA, Sebayang SK, Nandy R. Determinants of stunting in Indonesian children: Evidence from a crosssectional survey indicate a prominent role for the water, sanitation and hygiene sector in stunting reduction. BMC Public Health. 2016;16:669. https://doi.org/10.1186/ s12889-016-3339-8

PMid:27472935

5. Hure A, Oldmeadow C, Attia J. Invited commentary: Improving estimates of severe acute malnutrition requires more data. Am J Epidemiol. 2016;184(12):870-72. https://doi.org/10.1093/aje/ kww131

PMid:27856449

6. Khara T, Mwangome M, Ngari M, Dolan C. Children concurrently wasted and stunted: A meta-analysis of prevalence data of children 6-59 months from 84 countries. Matern Child Nutr. 2018;14(2):e12516. https://doi.org/10.1111/mcn.12516 PMid:28944990

7. Mwangome M, Ngari M, Fegan G, Mturi N, Shebe M, Bauni E, et al. Diagnostic criteria for severe acute malnutrition among infants aged under 6 mo. Am J Clin Nutr. 2017;105(6):1415-23. https://doi.org/10.3945/ajcn.116.149815

PMid:28424189

8. Mason-Jones AJ, Sinclair D, Mathews C, Kagee A, Hillman A, Lombard C. School-based interventions for preventing HIV, sexually transmitted infections, and pregnancy in adolescents. Cochrane Database Syst Rev. 2016;11:CD006417. https://doi. org/10.1002/14651858.CD006417.pub3

PMid:27824221

9. Bandura A. Social Learning Theory. Englewood Cliffs, NJ: Prentice Hall; 1977.

10. Kelly MP, Barker M. Why is changing health-related behaviour so difficult? Public Health. 2016;136:109-16. https://doi. org/10.1016/j.puhe.2016.03.030

PMid:27184821

11. Agustina R, Prafiantini E. Formative Research for an Improved Iron Folic Acid Supplementation Program for School Going Adolescents in Selected Districts of West Java Province in Indonesia. Indonesia: Department of Nutrition, Human Nutrition Research Cluster, Faculty of Medicine, Directorate of Research and Community Services, Universitas Indonesia and Nutrition International; 2016.

12. Angood C, Khara T, Dolan C, Berkley JA. Research priorities on the relationship between wasting and stunting. PLoS One. 2016;11(5):e0153221. https://doi.org/10.1371/journal. pone. 0153221

PMid:27159235

13. Briend A, Khara T, Dolan C. Wasting and stuntingsimilarities and differences: Policy and programmatic implications. Food Nutr Bull. 2015;36(1):S15-23. https://doi. org/10.1177/15648265150361S103 PMid:25902610

14. Bork KA, Diallo A. Boys are more stunted than girls from early infancy to 3 years of age in rural Senegal. J Nutr. 2017;147(5):940-7. https://doi.org/10.3945/jn.116.243246 PMid:28298540

15. Camaschella C. Iron deficiency anemia. N Engl J Med. 2015;372(19):1832-43. https://doi.org/10.1056/NEJMra1401038 
PMid:25946282

16. Castejon HV, Ortega P, Amaya D, Gomez G, Leal J, Castejon OJ. Anemia coexistence, vitamin a deficiency, and growth retardation in children 24-84 months in Maracaibo, Venezuela. Nutr Neurosci. 2013;7(2):113-9. https://doi.org/10.1 080/10284150410001704534

PMid:15279497

17. Lopez A, Cacoub P, Macdougall IC, Peyrin-Biroulet L. Iron deficiency anemia. Lancet. 2016;387:907-16. https://doi. org/10.1016/S0140-6736(15)60865-0

18. McDonald EM, Mack K, Shields WC, Lee RP, Gielen AC. Primary care opportunities to prevent unintentional home injuries: A focus on children and older adults. Am J Lifestyle Med. 2016;12(2):96-106. https://doi. org/10.1177/1559827616629924

PMid:27141210

19. Development Initiatives. Global Nutrition Report 2017 Nourishing the SDGs. Bristol, UK: Development Initiatives; 2017.

20. Gosdin L, Martorell R, Bartolini RM, Mehta R, Srikantiah S, Young MF. Anemia and stunting in young children. Matern Child Nutr. 2018;14:e12597. https://doi.org/10.1111/mcn.12597

PMid:29468825

21. Ministry of Health, Republic of Indonesia. Ministry of Health Anaemia Prevention and Control Program in Adolescent Girls and Women of Reproductive Age. Indonesia: Ministry of Health, Republic of Indonesia, 2016. 